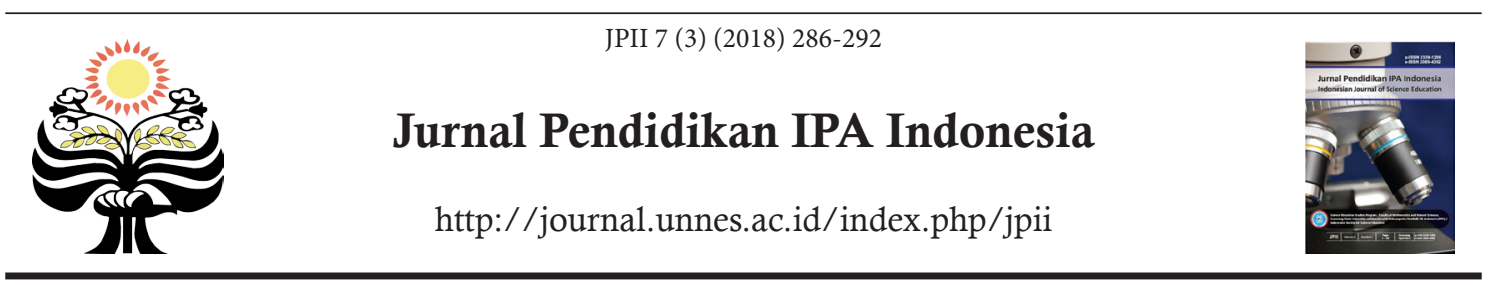

\title{
ECOLOGICAL STUDIES OF Oryctes rhinoceros LARVAE CONTROLLED BY Metarhizium anisopliae AND ENTHOMOPATOGENIC NEMATODES
}

\author{
D. R. Indriyanti ${ }^{* 1}$, R. Rahmawati ${ }^{2}$, B. Priyono ${ }^{3}$, M. Slamet ${ }^{4}$, F. Z. Huyop ${ }^{5}$ \\ ${ }^{1,2,3}$ Biology Department, Faculty of Mathematics and Natural Sciences, \\ Universitas Negeri Semarang, Indonesia \\ ${ }^{4}$ Estate Crop Protection Board in Salatiga, Central Java, Indonesia \\ ${ }^{5}$ Faculty of Biosciences and Medical Engineering, Universiti Teknologi Malaysia, Malaysia
}

DOI: 10.15294/jpii.v7i3.14239

Accepted: May 23rd 2018. Approved: August 31 ${ }^{\text {st }}, 2018$. Published: September $20^{\text {th }}, 2018$

\begin{abstract}
Oryctes rhinoceros L. (Coleoptera: Scarabaeidae) is a pest of coconut plant. Metarhizium anisopliae and Enthomopatogenic Nematodes are biological control agents. The purpose of this study was to determine the ecology of insect pests controlled by fungi Metarhizium anisopliae (MET), Enthomopatogenic Nematodes (NEP) and the mixture of MET and NEP for controlling O. rhinoceros larvae on the field. M. anisopliae used was in the form of kaolin powder formulation (WP). The nematodes used were Heterorhabditios sp. Nematodes formulation was in the form of liquid with sponge medium contained 10 x 106 NEP in every pack. The study used Randomized Block Design with 3 types of treatment and 10 times repetition on 10 larvae. The result of six weeks treatment showed that the highest larval mortality was obtained from the treatment with the mixture of MET and NEP. Biological control using two biological agents (MET and NEP) is better than only MET or NEP. The benefit of research is for the recommendation of $O$. rhinoceros larvae control.
\end{abstract}

(C) 2018 Science Education Study Program FMIPA UNNES Semarang

Keywords: application of Metarhizium anisopliae, Enthomopatogenic Nematodes, Oryctes rhinoceros, biological control.

\section{INTRODUCTION}

Oryctes rhinoceros beetle is one of the major pests attacking coconut crops in Indonesia (Indriyanti et al., 2018). It has reportedly attacked the coconut plants in Africa, especially in Pacific Island (Jackson, 2009), in Malaysia (Manjeri et al., 2014), Arab (Khudhair et al. 2015). Jepara, located on the Shore of Java Sea, Indonesia (Indriyanti et al., 2018). We have studied O. rhinoceros in Jepara, Indonesia since 2015. The beetle destroy the coconut shoot, attacks on growing point of stem while the larvae live in the soil or dead coconut trunk (Moslim et al., 2011). Control larvae with pesticides causes various negative impacts on the environment such as soil, water, and air (Amalia \& Yusa, 2018). One of the biological agent to control the larvae of O.rhinoceros is Metarhizium anisopliae (Latifian \& Rad, 2012). It is a parasitic fungus that infect many insects (Agali et al., 2017). Beside fungus, there is nematode netomopatogen which also attack insect. Both are safe for the environment, because it does not cause environmental pollution and does not cause resistance to insect pests (Hajek \& Delalibera, 2010; Divya \& Sankar, 2009). 
The semi-field study was conducted in Jepara to analyze the effect of MET, NEP and the mixture of both substances on the $O$. rhinoceros larval mortality. The treatment was conducted in coconut plantation owned by the local people using pots containing soil medium with organic material. The results showed that controlling $O$. rhinoceros larvae with the mixture of MET and NEP resulted in faster larval mortality (2-5 weeks) than the treatment with the MET (2-7 weeks) or the NEP (2-8 weeks), while larval mortality without the administration of MET or NEP (control) was $13-20 \%$, the larvae that remained alive was $80-87 \%$ (Indriyanti at al., 2017). Ecological research has never been done in Jepara, therefore it is necessary to do.

The MET and NEP applications on a semi-field scale have been proven effective in controlling the $O$. rhinoceros larvae. However, the results of the application of MET and NEP in a field have not been reported yet. The biological control of $O$. rhinoceros larvae with parasitic fungus (MET) and (NEP) offers environmentally friendly pest controls without the emerge of pest resistance. Therefore, it is necessary to conduct a research for the purpose of analyzing the effect of MET and NEP application for controlling $O$. rhinoceros larvae on a field scale.

\section{METHODS}

This study was conducted in Jerukwangi, Jepara, Indonesia. This study used Randomized Block Design with three types of treatment (MET, NEP, and the mixture of MET and NEP). The population in this study was all $O$. rhinoceros larvae in Jerukwangi Village. The samples in this study were 330 O. rhinoceros larvae ( $3^{\text {rd }}$ instar) obtained from nests in the field. The larvae were collected by digging the suspected place. The places where larva often encounters were in the piles of cattle dung (cows and goats), the livestock fodder, garbage piles, and rotted coconut trunks. The recorded abiotic factors were temperature, air humidity, soil $\mathrm{pH}$, soil moisture, and light intensity. 100 grams of soil was taken to check the soil moisture content.

\section{The Application of M. Anisopliae (MET)}

The MET used was in the form of conidia with kaolin powder formulation (ZIUM ORWP) obtained from BPTBUN Salatiga. The conidial density was $2.50 \times 10^{8}$ conidia $L^{-1}$, with the viability of $93 \%$. Treatment places were in the same places where the larvae were found, which were then called nests. The size of the nest was $1 \mathrm{x} 1 \mathrm{x}$
$0.3 \mathrm{~m} .100$ grams of MET was added to the soil (in the nest) and then stirred in depth of $0.3 \mathrm{~m} .10$ larvae were placed in the nest. The location was covered by a net (hole size of $3 \times 3 \mathrm{~mm}$ ) and then be marked. This closure aimed to avoid the interference from the outside. The MET treatment was repeated 10 times. For comparison (control), the same procedure was applied in the other nest without the administration of MET. Data collection was conducted once a week for 6 weeks by counting the MET-infected larvae.

\section{The Application of Entomopathogenic Nematodes (NEP)}

The nematodes used were Heterorhabditios sp obtained from the Plant Pest and Disease Department, Faculty of Agriculture, Jember. The nematodes formulation was in the form of liquid with sponge media containing $10 \times 10^{6} \mathrm{NEP}$ per pack. The recommended dosage of NEP is one plastic package for 1 spray tank (14 liters) for 500 $\mathrm{m} 2$. Based on the preliminary research, the dose of dilution for application in the field scale was needed to be improved, so that the dilution used was 3.5 liters for one package. The application of the nematodes was conducted by spraying the NEP solution to the nest (soil) with the size of $1 \mathrm{x}$ $1 \times 0.3 \mathrm{~m}$. Ten larvae were then placed in the nest. As a control, water was splashed to the ground to replace the NEP solution. The NEP treatment was repeated 10 times with one control. Both treatment and control nest were covered by a net and then marked. Data collection was conducted once a week for 6 weeks.

\section{The Application of the Mixture of MET and NEP}

The same procedure as the MET and NEP treatments were applied in this treatment. The dosage used was 100 grams of MET combined with 1 pack of NEP in 3.5 liters of water, while for comparison, the control nest was administered only by the water (without MET and NEP). The treatment was repeated 10 times with one control. Both treatment and control nest $(1 \times 1 \mathrm{~m})$ were covered by a net and then marked. Observations were conducted once a week. The nest was dismantled and the characteristics or symptoms of infected larvae were then observed. The observations were performed until all the larvae in the nest died. The dead larvae were observed in the Biology Laboratory of Universitas Negeri Semarang to ascertain that the death of larvae was caused by the infection of MET or NEP. Data collection was conducted once a week for six weeks. 


\section{RESULTS AND DISCUSSION}

\section{The Application of M. anisopliae (MET)}

The results of observation showed that MET-infected larvae were initially characterized by the appearance of dark brown necrotic spots at the location of the hyphae penetration on the body of larvae. In addition, the larvae showed behavioral changes in form of laziness, slow motion, loss of coordination ability, decreased in feeding activity and the change in color (from white into dull). According to Gusmara (2011), the dark brown necrotic spots are a sign of melanization that indicates a fungal infection occurs in the larvae. Melanization is a form of self-defense against fungal infections that serve to inhibit the growth of fungi in the body of the larvae. The dark brown necrotic spots are melanin produced by phenol compounds catalyzed by phenol oxidase enzymes.

The MET-infected dead Larvae were characterized by a hardened body (mummification) and the growth of fungus MET on the entire body of larvae. The color of hyphae changed from white to green along with the increasing age. According to Jackson \& Jaronski (2009), mummification occurs in the larval body because all tissues and body fluids of larvae used up for the proliferation of MET. The observation results on larval infection symptom are presented in Figure 1 .

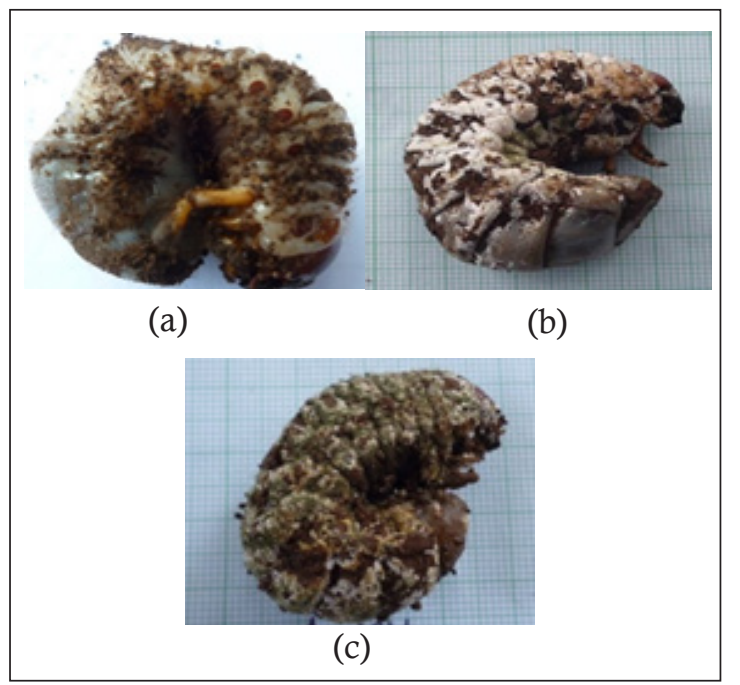

Figure 1. The Symptom of MET Infection on $O$. rhinoceros larva. (a) Dark Brown Necrotic Spot; (b) White MET Hyphae; and (c) MET Hyphae that Turned into Dark Green. The Hardened Body of the Larva.

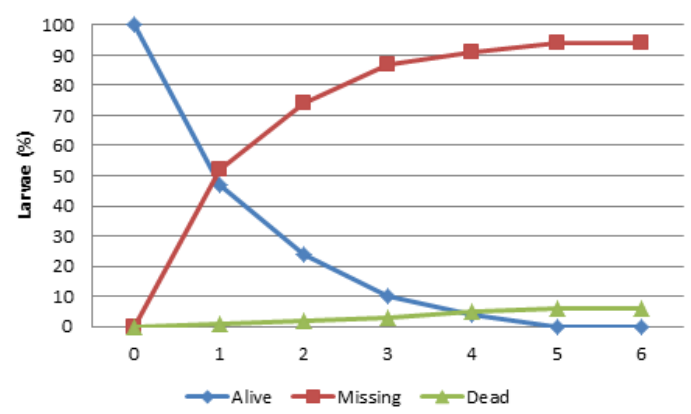

Figure 2. The Percentage of Alive, Missing and MET-Infected Dead Larvae of $O$. rhinoceros with the treatment Using $100 \mathrm{gr} / \mathrm{m}^{2} \mathrm{MET}$ on 6 Weeks of Treatment Period.

Based on Figure 2, it is known that MET application on $O$. rhinoceros nest resulted in many missing larvae. The larvae were not found at the observation site (nest). Larval control effort on the nest could only kill $6 \%$ of the larval population. The missing larva is an interesting phenomenon, which has not occurred in the previous study (treatment with the pots). In the previous study, the MET-infected larval mortality can reach $100 \%$ in the 7th week (Latifian \& Rad, 2012). This might happen because the larvae were isolated in pots. In the field, the result was very different because the larvae can easily and freely move away from the treated place.

The larval mortality rate as a result of MET treatment only reached $6 \%$ until the last day of observation (Figure 2). This was related to the many-disappeared larvae from the treated nest. The death of larvae was caused by the fungal infection. According to Bedford (2013), the larval stages of $O$. rhinoceros actively looked for substrates that contained lots of organic material as a source of food. Larvae moved out of the treated nest because the source of organic materials used to feed was finished and they looked for a source of more abundant organic material outside the nest.

Some of the missing larvae were found around the nest. They were still alive and some of them were going into the soil deeper. Larvae turned active, looking for food that has not been eaten. This resembles the cultivation of earthworms. When the dirt has been eaten, the worm moves to another place around the media. The larvae move away horizontally from the nest because they want to get food around it. The larvae also moved vertically to avoid the light. The movement of larvae into the soil was reported by 
Pujiastuti (2010) who found that most urethral larvae were at a depth of more than $30 \mathrm{~cm}$, followed by a depth of $20 \mathrm{~cm}$, and $10 \mathrm{~cm}$.

The results of this study showed that the speed of MET infection was not comparable with the active movement of the larvae. The fungal conidia took at least 18 hours to germinate (viability), then stick to the skin, infect and breed in the body of larvae. It took at least two days for the MET to infect the larvae. This was in accordance with previous research found that the larvae take 2-7 weeks to die. Therefore, controlling the 3 rd instar larvae of $O$. rhinoceros in the nest was ineffective. The larvae tended to move actively to avoid the passive mushrooms in the nest. In addition, the 3rd instar larvae have a thick cuticle, so, the MET required a longer time to cause an infection.

The larval mortality is influenced by the pathogenicity of MET conidia. The pathogenicity is determined by the number of conidia that are able to germinate (viability). The higher the viability of conidia, the higher pathogenicity they have. The high viability of MET conidia is influenced by environmental factors. According to Moslim et al. (2011), conidia viability is strongly influenced by environmental factors such as temperature, $\mathrm{pH}$, moisture and water content of the media. The temperature in the Jerukwangi Village was $30-33^{\circ} \mathrm{C}$. According to Pracaya (2004), the ideal temperature for the growth of MET ranges from $22-27^{\circ} \mathrm{C}$. The presence of dead larvae infected by MET proved that the temperature ranging from $30-33^{\circ} \mathrm{C}$ is still possible for the growth of MET. The soil $\mathrm{pH}$ in the study site ranged from 6.7 to 7 , which was a proper $\mathrm{pH}$ for the growth of the MET. The soil $\mathrm{pH}$ at the time of MET application was very important because it was related to the work of MET enzymes. According to Paula et al. (2011), an appropriate $\mathrm{pH}$ for the growth of MET ranges from 3.3-8.5 and optimum growth occurs at $\mathrm{pH} 7$. The air humidity in this study ranged from $68-87 \%$. It was suspected to be the cause of low MET infection rate. Jackson \& Jaronski (2009) reported that the pathogenicity of the MET decreased when the air humidity was below $86 \%$. The intensity of light in this study ranged from $360-860$ Lux because the location of the treated nest was in a place shaded by trees, so it was not too exposed to sunlight.

The MET-treated nest would be effective for early instar larvae. It would be more effective when the MET initially applied in the nest and the female put the eggs in that nest, then the eggs hatched releasing the 1st instar larvae. Those larvae would be easily infected because their skin is relatively soft and they are not yet actively moving. Therefore, for the MET-treatment of the 3rd instar larvae, they should be placed in a particular container. After the larvae were infected and died, then they could be made into an inoculum at the nest site.

\section{The Application of Entomopathogenic Nematodes (NEP)}

The observation on larvae infected by NEP showed changes in larval body color from clean white to brownish-black and the texture of the larval body became mushy. These results are in accordance with the statement of Sucipto (2008) that the symptoms of NEP attack on host insects are characterized by changes in the color of the body surface to dark brown. The body also became soft and so the tissue became aqueous. Changes in body color of $O$. rhinoceros larvae were due to the bacterial reaction of the Photorhabdus sp symbionts in the digestive tract of nematodes. The enzymatic activity of Photorhabdus sp bacteria caused the destruction of the larval tissue resulting in black dead larvae (Suyanto et al., 2012). Figure 3 shows the $O$. rhinoceros larvae infected by NEP.

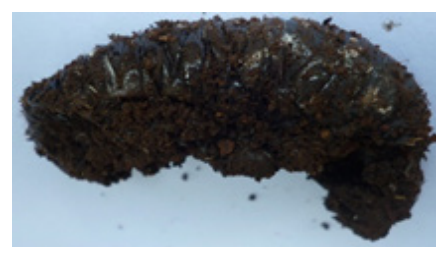

Figure 3. O. rhinoceros Larva Infected by Heterorhabditios sp Entomopathogenic Nematodes (NEP).

The result of observation on the application of NEP on O. rhinoceros larval nest for 6 weeks is presented in Figure 4.

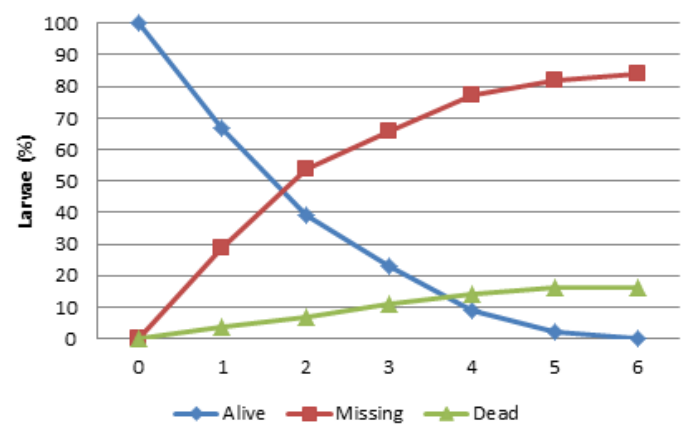

Figure 4. The Percentage of alive, missing and NEP-infected dead larvae of $O$. rhinoceros with the treatment using 3.5 liters dilution of NEP on 6 weeks of treatment period. 
Figure 4 shows the same symptom as in the application of MET (Figure 2). The loss of larvae was assumed to be related to the food availability. The larvae were commonly found on the outside of the nest moving toward the new food sources. The percentage of larval mortality showed an increase in the 1 st week (4\%) to the 6 th week $(16 \%)$. The results were different compared with the previous study which used pots resulting in $100 \%$ the larval mortality on the 8th week (Latifian \& Rad, 2012).

The results of this study indicated that speed of NEP in infecting the larvae was not comparable to the speed of larval move avoiding the NEP. The NEP needed time to find the natural holes in the body of the larvae, enter the body, and then infect the larvae. The NEP-infected larvae were those that did not move away from the location. Therefore, the addition of NEP to the nest could only control $16 \%$ of the larval population. The nematodes have a killing effect on their host because NEP is symbiotic with NEP-induced bacteria. According to Noguez et al. (2012), the NEP of the Heterorhabditidae family is symbiotic with the Photorhabdus sp. bacterium. The symbiotic bacteria coming out of the NEP after the penetration into the larval body release a toxin causing the O. rhinoceros larvae to die (Kaya, 1993).

The nematode's killing ability is not only determined by the symbiosis between the NEP and the symbiotic bacteria but also the self-defense of $O$. rhinoceros larvae. In this study, the larval movement away from the nest was an effort to defend them from being infected with NEP. Environmental conditions such as temperature, sunlight intensity, humidity, and the rainfall influenced the NEP activity in the soil. Temperature measurements in the study ranged from 30-330C, which was still possible for NEP activity. It was evidenced by the presence of dead larvae infected by the NEP. According to Adam \& Nguyen (2002), nematodes could increase their activity by $80 \%$ at a temperature of $21-30 \mathrm{oC}$ and decreased at a temperature of $12-160 \mathrm{C}$. The soil moisture ranged during the study was $49-70 \%$. According to Suyanto et al. (2012), moisture was the most important thing that affected the activity of NEP in the soil. An appropriate soil moisture ranged from $40-90 \%$.

The NEP applications in the field were conducted in April-June with high rainfall ranging from 100-200 $\mathrm{mm}$ (Weather \& Climate
2016). The continuous intensity of rainfall allowed the NEP carried by the rain. According to Manan \& Suyanto (2009), not all NEP could enter the body of the larvae, this was due to the environmental factors such as excessive rainfall that could wash away the NEP. Therefore, the rainfall was the main factor of the low probability of NEP penetration to the body of the larvae.

\section{The Application of the Mixture of $M$. anisopliae (MET) and Entomopathogenic Nematodes (NEP)}

The observation results showed variety symptoms of larval death, among which the larvae were infected by the MET (Figure 1), the NEP (Figure 3), and the mixture of MET and NEP in a single larval body. The larvae infected by the mixture of MET and NEP showed a symptom in form of the hyphae growth on the entire larval body except for the abdomen. The texture of the body hardened on the part where the hyphae grew, while the abdomen was mushy with the appearance of blackish brown color. According to Jackson \& Jaronski (2009), the occurrence of hardening (mummification) in the body of $O$. rhinoceros larvae was due to the tissue and body fluids of larvae which have been used up by the MET. The abdominal portion of $O$. rhinoceros larvae was suspected to be infected with the NEP. It was in accordance with the statement of Afifah et al. (2013) and Latifian \& Rad (2012) that the symptoms of insects infected by the NEP are marked by a change of color, the body becomes tender because the tissue in the body becomes liquid. The appearance of larvae infected with MET and NEP is presented in Figure 5.

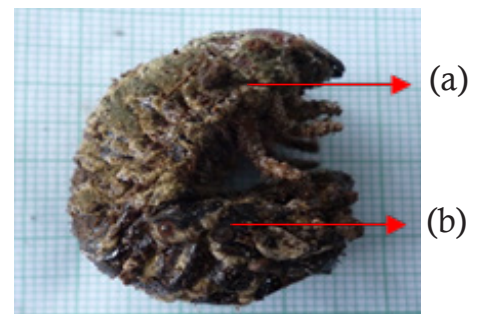

Figure 5. O. rhinoceros larvae infected by the mixture of MET and NEP. (a) part of the body that is infected by MET; and (b) part of the body that is infected by NEP

The observation results on the application of MET and NEP mixture on $O$. rhinoceros larval nest for 6 weeks appear in Figure 6. 


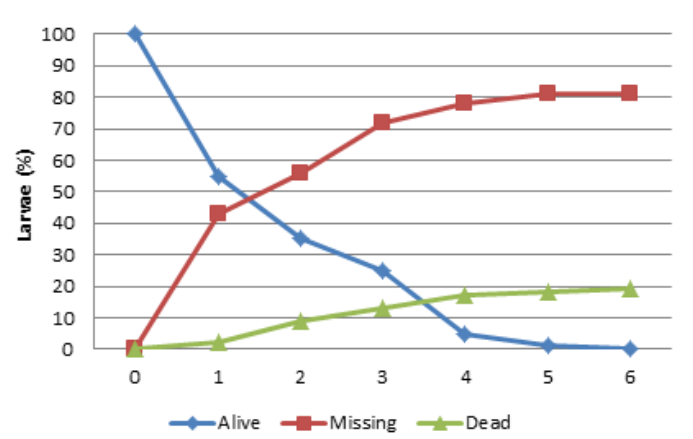

Figure 6. The Percentage of Alive, Missing and MET-infected Dead Larvae of $O$. rhinoceros with the Treatment Using the Mixture of $100 \mathrm{~g} / \mathrm{m}^{2}$ of MET and 3.5 Liters Dilution of NEP on 6 Weeks of Treatment Period.

Figure 6. shows almost the same results as the treatment using the MET (Figure 2) and NEP (Figure 4). Many larvae are not found in the observed nest. However, the dead larvae found in this treatment $(19 \%)$ are more than the ones found on the treatment using only MET $(6 \%)$ or only NEP (16\%) (Figure 7). In percentage, there was an increase in the number of dead larvae. The mechanism suspected underlying the synergy between MET and NEP was that the MET or NEP-infected larvae condition would be weaker and more susceptible to the subsequent infections. This is consistent with the study by Ansari et al. (2008) showed that the MET-infected larvae will be weaker and vulnerable to the infection of NEP infection. This fact corresponded to the decrease in larval activity resulted in a higher probability of NEP infection.

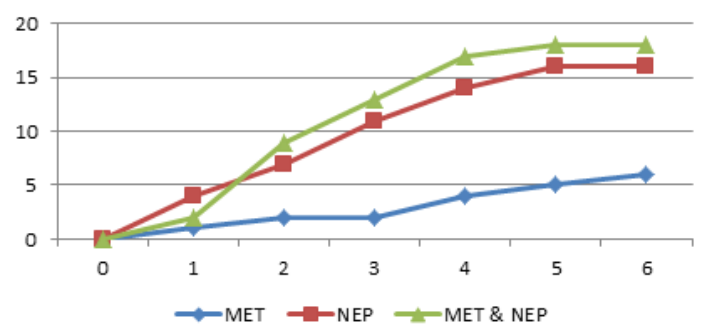

Figure 7. The Percentage of $O$. rhinoceros Dead Larvae with the Treatment Using the MET, NEP and MET + NEP on 6 Weeks of Treatment Period.

Mixing the MET and NEP in this study was expected to accelerate the process of infection so that the process of controlling $O$. rhinoceros would be accelerated too. However, the results showed that economically the mixture of MET and NEP was not favorable because of a small difference in larval mortality (3-13\%). Therefore, it was suggested to choose only one kind of substances. In this treatment, many larvae indicated the symptoms of MET and NEP infection, but the most found were the NEP symptoms (mushy larval body). The results of the field test were very different compared with the semi-field test using pots, in which the larval mortality reached $100 \%$ at the 5 th week. The research benefit was the recommendation of $O$. rhinoceros larvae control in the field.

\section{CONCLUSION}

The results of MET, NEP, and the mixture of MET and NEP application on O. rhinoceros larvae in the field showed that there were many larvae missing from the nest and moving both horizontally and vertically. The larval mortality as a result of the application of MET, NEP, and the mixture of MET and NEP on the 6th week are $6 \%, 16 \%$, and $19 \%$ respectively. The control using two biological agents (MET and NEP) was better than the MET or NEP only.

\section{REFERENCES}

Adams. B.J \& Nguyen, K.B. (2002). Taxonomy and Systematics. Pp 1-28 in: R. Gaugler (Ed). Entomopathogenic Nematology. CAB International, Wallingford, Oxford.

Afifah, L., Rahardjo, B. T., \& Tarno, H. (2013). Eksplorasi Nematoda Entomopatogen pada Lahan Tanaman Jagung, Kedelai dan Kubis di Malang Serta Virulensinya terhadap Spodoptera litura fabricius. Jurnal Hama dan Penyakit Tumbuhan, 1(2), 1-9.

Agali, A.E.A., Mohammed, E.A.E.R., Hassan, A.E.W. (2017). Effect of Entomopathogenic Fungi Metarhizium anisopliae var acridum and Beauveria bassiana on Survival of Anopheles arabiensis Patton and Culex quinquefasciatus Say Mosquito Larvae. Sudan Journal of Science, 9(2), 26-40.

Amalia, A.V \& Yusa, M.H. (2018). Control Pest of Leaf Caterpillars (Plutella xylostella) in Delima Rose Apples Using Soursop Leaf Extract ( $A n$ nona muricata). Jurnal Pendidikan IPA Indonesia. $7(1), 1-8$.

Ansari, M.A,. Shah, F.A. \& Butt T.M. (2008). Combined Use of Entomopathogenic Nematodes and Metarhizium anisopliae as a New Approach for Black Vine Weevil, Otiorhynchus sulcatus, Control. Entomologia Experimentalis et Applicata, 129(3), 340-347.

Bedford, G. O. (2013). Long-term Reduction in Damage by Rhinoceros Beetle Oryctes rhinoceros (L.) (Coleoptera: Scarabaeidae: Dysnastinae) to Coconut palm at Oryctes Nudivirus release Site on Viti Levu, Fiji. African Journal of Agricultural 
Research, 8(49), 6422-6425.

Divya, K., \& Sankar, M. (2009). Entomopathogenic Nematodes in Pest Management. Indian Journal of Science and Technology, 2(7), 53-60.

Gusmara, B.H. (2011). Pembuatan dan Pengujian Formula Metahizium majus UICC 295 dengan Media Pembawa Substrat Beras (Oryza sativa) terhadap Larva Oryctes rhinoceros. (Skripsi). Depok: Universitas Indonesia.

Hajek, A. E., \& Delalibera, I. (2010). Fungal Pathogens as Classical Biological Control Agents against Arthropods. BioControl, 55(1), 147-158.

Indriyanti, D. R., Lutfiana, J. E., Widiyaningrum, P., Susilowati, E., \& Slamet, M. (2018, March). Aggregation Pheromones for Monitoring the Coconut Rhinoceros Beetle (Oryctes rhinoceros) in Jerukwangi Village, Jepara, Indonesia. In Journal of Physics: Conference Series (Vol. 983 , No. 1, p. 012177). IOP Publishing.

Indriyanti, D.R., Widiyaningrum, P., Haryuni, Slamet, M. \& Maretta,Y.A. (2017). Effectiveness of Metarhizium anisopliae and Entomopathogenic Nematodes to Control Oryctes rhinoceros Larvae in the Rainy Season. Pakistan Journal of Biological Sciences, 20(7), 320-327.

Jackson, M. A., \& Jaronski, S. T. (2009). Production of Microsclerotia of the Fungal Entomopathogen Metarhizium anisopliae and Their Potential for Use as a Biocontrol Agent for Soil-Inhabiting Insects. Mycological Research, 113(8), 842-850.

Jackson, T. A. (2009). The Use of Oryctes Virus for Control of Rhinoceros Beetle in the Pacific Islands. In Use of Microbes for Control and Eradication of Invasive Arthropods (pp. 133-140). Springer, Dordrecht.

Kaya, M.G. (1993). Efficiacy Against Soil-Inhibitting Insect Pests. In: Gauler Kaya H K. (Ed) Entomophatogenic Nematodes in Biological Control. Florida: CRC Press.

Khudhair, M.W., Khalaf, M.Z., Alrubeai, H.F., Shbar, A.K., Hamad, B.S., Khalaf H.S. 2015. Evaluating the Virulence of Metarhizium anisopliae (Deuteromycotina: Hyphomycetes) and Beauveria bassiana (Ascomycota: Hypocreales) isolates to Arabian rhinoceros beetle, Oryctes agamemnon arabicus. Journal of Entomological and Acarological Research, 47(3), 117-122.

Latifian, M., \& Rad, B. (2012). Pathogenicity of the Entomopathogenic Fungi Beauveria bassiana (Balsamo) Vuillmin, Beauveria brongniartii Saccardo and Metarhizium anisopliae Metsch to Adult Oryctes elegans Prell and Effects on Feeding and
Fecundity. International Journal of Agriculture and Crop Sciences, 4(14), 1026-1032.

Manan, A \& Suyanto, A. (2009). Kemempanan Isolat Lokal Nematoda Entomopatogen Steinernema carpocapsae Poinar Untuk Pengendalian Hama Ulat Grayak (Spodoptera litura F.). Jurnal Pembangunan Pedesaan, 9(1), 35-42.

Manjeri G, Muhamad, R \& Tan, S.G. (2014). Oryctyes rhinoceros Beetles, an Oil Palm Pest in Malaysia. Annual Research \& Review in Biology, 4(22), 3429-3439.

Moslim, R. A. M. L. E., Kamarudin, N., \& Wahid, M. B. (2011). Trap For the Auto Dissemination of Metarhizium Anisopliae in the Management of Rhinoceros Beetle, Oryctes Rhinoceros. $J$. Oil Palm Res, 23, 1011-1017.

Noguez, J. H., Conner, E. S., Zhou, Y., Ciche, T. A., Ragains, J. R., \& Butcher, R. A. (2012). A Novel Ascaroside Controls the Parasitic Life Cycle of the Entomopathogenic Nematode Heterorhabditis Bacteriophora. ACS chemical biology, 7(6), 961-966.

Paula, A. R., Carolino, A. T., Paula, C. O., \& Samuels, R. I. (2011). The Combination of the Entomopathogenic Fungus Metarhizium anisopliae with the Insecticide Imidacloprid Increases Virulence against the Dengue Vector Aedes aegypti (Diptera: Culicidae). Parasites \& vectors, 4(1), 8.

Pracaya. 2004. Hama Penyakit Tanaman. Depok: Penebar Swadaya.

Pujiastuti, Y. (2010). Tingkat Populasi dan Kebugaran Oryctes rhinoceros L Coleoptera: Scarabaeidae di Perkebunan Kelapa Sawit (Elaeis Guineensis Jacq). Prosiding Seminar Nasional Penelitian Bidang Pertania. Vol 2.

Sucipto. (2008.) Persistensi Nematoda Entomopatogen Heterorhabditis (All Strain) Isolate Lokal Madura terhadap Pengendalian Rayap Tanah Macrotermes sp. (Isoptera: Termitidae) di lapang. Jurnal Embryo, 5(2), 193-208.

Suyanto, A., Srimurni, E \& Djuharyanto, T. (2012). Perkembangan Larva Serangga Hama Kumbang Badak (Oryctes rhinoceros L.) pada Berbagai Konsentrasi Isolat Nematoda Entomopatogen Heterorhabditis sp. Prosiding Seminar Nasional ISBN: 978-979-9204-79-0; Purwokerto.

Weather and climate. (2016). Average, Monthly, Precipitation, Rainfall Jepara Central Java. Retrieved from https://weather-and-climate.com/average-monthly-precipitation-Rainfall,jepara-central-java-id,Indonesia 